\title{
THE FREQUENT OCCURRENCE OF UNDERFEEDING IN EARLY INFANCY.
}

BY

\author{
DONALD PATERSON, M.B., M.R.C.P.
}

Physician to Out-patients, Hospital for Sick Children, Great Ormond Street, Physician in Charge of Children's Department, Westminster Hospital, London.

AND

\section{A. MARR-GEDDES, M.B., Ch.D.}

In this short paper we shall attempt to prove that in hospital practice the vast majority of infants brought up for gastric symptoms and failure to gain are underfed. This proposition represents an opinion long entertained by one of the writers as a result of his clinical observations, but so far as we are aware, its truth or falsity has not been hitherto tested by a statistical study. We have, therefore, taken one hundred cases from the out-patient notes of patients attending one of us (D.P.) at The Hospital for Sick Children, Great Ormond Street in 1926 and 1927 . We should like to emphasise the fact that the hundred cases discussed were taken indiscriminately and not specially selected.

Infants from the age of six months downwards were regarded as best illustrating the object in view, and both the breast-fed and the artificially-fed have been considered.

An important point must be remembered in estimating the gains in weight after the correction of the diets, i.e., that every infant, unless definitely suffering from a fat-diarrhœa, was ordered cod liver oil emulsion. A grain of chloral hydrate was also given three times daily for a period of one week.

\section{Breast Fed Infants.}

Group I. Underfeeding on the Breast.

In our series there were 28 of the above type, 15 males and 13 females.

\begin{tabular}{c|c|c|c|c|c}
\hline Sex. & Av. birth wt. & $\begin{array}{c}\text { Av. age } \\
\text { at } \\
\text { examination. }\end{array}$ & $\begin{array}{c}\text { Av. wt. } \\
\text { at } \\
\text { examination. }\end{array}$ & $\begin{array}{c}\text { Av. gain per } \\
\text { week after } \\
\text { correction } \\
\text { of feed. }\end{array}$ & $\begin{array}{c}\text { Approx. } \\
\text { " below level " } \\
\text { weight. }\end{array}$ \\
\hline M. & $7 \mathrm{lb} .6 .8 \mathrm{oz}$. & $9 \cdot 46$ weeks & $8 \mathrm{lb} .13 \mathrm{oz}$. & $11.25 \mathrm{oz}$. & $\begin{array}{c}2 \mathrm{lb} .15 \mathrm{oz} . \\
\text { per infant. } \\
\text { F. }\end{array}$ \\
\hline
\end{tabular}


The routine adopted was the giving of complementary feeds, that is, additional artificial feeds immediately after the breast. In no case was the child taken off the breast. In making the diagnosis a test feed was invariably carried out.

Among these 28 cases were three of about six months who obviously wanted a starch complement (groats, soup, etc.), while in another infant of two months the mother, though short of breast milk, was very irregular in giving the complementary feed, with the result that the infant gained only $5 \mathrm{oz}$. per week.

One infant of 4 months was suffering from diarrhœa and vomiting which disappeared when a thick complementary feed was given.

Only one case of breast-fed rickets .was recorded, an infant of 4 months, who did well on a complementary diet in the form of starches, such as groats, patent barley, cream of rice, Allenbury's No. 3, bone and vegetable soup, etc.

Apart from failure to gain. "air swallowing" in these hungry babies probably accounted for the three other chief symptoms commonly noted, viz., vomiting, screaming and frequency of defæcation. The underfed infant, being left at the breast longer than is necessary, tends to swallow wind; that is, having obtained all the mother's supply in say 2 or 3 minutes, for the next 5 minutes continues to suck and at the same time swallow air. The following sequence of events then occurs. The stomach being fully distended, the child feels comfortable and dozes at the breast, appearing satisfied. A portion of the swallowed air passes through the pylorus into the bowel, producing increased peristalsis by distending the bowel. The result is frequent, small, explosive motions each time the infant is placed to the breast. The portion of the air remaining in the stomach is eructated and some of the food is brought up with it.

Example. A male infant, L.R., birth weight $8 \mathrm{lb} .5 \mathrm{oz}$. presented itself at the age of 5 weeks weighing $9 \mathrm{lb} .4 \mathrm{oz}$. The child was entirely breast fed, and a test feed showed an insufficiency of breast milk. Complementary feeds of cow's milk and water were added and there was a gain of 11 ozs. in the following 7 days. Diagnosis-underfeeding on the breast.

Group II. Overfeeding on the Breast.

Only one case was met with in an infant of eleven weeks of age, weighing $12 \mathrm{lb} .14 \mathrm{oz}$., which, on having its feed regulated and reduced stopped screaming and continued an average increase weekly.

Overfeeding on the breast is said to be extremely common. Whether this be so or not we offer no opinion, but we would deny that serious pathological disturbances are produced in any number of infants by overfeeding on the breast. In this large series of ailing infants we are only able to record one case, although the possibility was always present to our minds. The infant who is being overfed on the breast would seem to adjust itself rapidly to its feed by occasional small vomits and an increased number of stools. The gain in weight in the overfed infant on the breast is as a rule excessive.

Group III. Underfeeding in Breast-fed Infants, already having complementary feeds.

In this class there were eight cases, presenting themselves with different forms of gastric disturbance and failure to gain. Three, apart from the breast, 
were having complementary feeds of Cow and Gate, one Nestlés, one Almata, one Allenbury's, one cow's milk and one cow's milk and Virol.

\begin{tabular}{c|c|c|c|c}
\hline Av. birth wt. & $\begin{array}{c}\text { Av. age at } \\
\text { examination. }\end{array}$ & $\begin{array}{c}\text { Av. wt. at } \\
\text { examination. }\end{array}$ & $\begin{array}{c}\text { Av. gain per } \\
\text { week after } \\
\text { correction } \\
\text { of feed. }\end{array}$ & $\begin{array}{c}\text { Approx. } \\
\text { "below level " } \\
\text { weight. }\end{array}$ \\
\hline $7.96 \mathrm{lb}$. & 14 weeks & $10.98 \mathrm{lb}$. & $8.53 \mathrm{oz}$. & $2 \mathrm{lb} .10 \mathrm{oz}$. \\
\hline
\end{tabular}

It will be noticed that the average age and weight at the examination is higher than in the first-class (purely breast fed) owing no doubt to the fact that the mother in each case was aware of the deficiency in her breast milk and attempted complementary feeding for some time of her own accord before bringing the infant up to Hospital.

Example. A male infant, C.S., birth weight $7 \mathrm{lb} .10 \mathrm{oz}$., was seen at the age of 10 weeks weighing $10 \mathrm{lb} .6 \mathrm{oz}$., fed at the breast and getting complementary feeds of Allenbury No. 1. The symptoms complained of were flatulence, irritability and failure to thrive. A complementary feed of cow's milk, water and sugar was given and there was a gain of $17 \mathrm{oz}$. in 14 days. Diagnosis-underfeeding on the breast, with insufficient complementary feeding.

\section{Group IV. Rumination Cases (Merycism).}

Four of these cases are included in our series. One was being fed on Glaxo, one on peptonised cow's milk, one on cow's milk and another on the breast, with a complementary feed of Nestle's.

The average weight at birth was $8 \mathrm{lb}$.

The average age at examination was 18.5 weeks.

The average weight on examination was $9 \mathrm{lb} .6 \mathrm{oz}$.

The average gain per infant per week after correction of diet was $15 \cdot 66 \mathrm{oz}$.

Alteration in the diet was made by thickening the feeds in all four cases, and the enormous average gain was very gratifying. One infant actually put on $28 \mathrm{oz}$. in 7 day, another $25 \mathrm{oz}$. in 7 days. The approximate " below level " weight for this class at their average age was $6 \mathrm{lb} .2 \mathrm{oz}$. per infant.

It would appear to us that this class of case tends to go undiagnosed. The clinical picture is clear cut. The infant fails to gain weight, the vast majority being extremely bright infants, more often females. The initial feed is often of a sweet nature and too large in amount, tending to cause regurgitation. The habit of regurgitating the food is thus formed by the infant, and quite rapidly some of each feed is regurgitated at intervals, until the stomach is empty, or until the time of the next feed. The mother's complaint is that " the pillow is always wet," although she seldom complains of large vomits. The result of giving thickened, concentrated feeds is dramatic, as shown by our figures.

Example. A female infant, M.E., birth weight, $6 \mathrm{lb} .14 \mathrm{oz}$. , was seen at the age of six months, weighing $7 \mathrm{lb} .3 \mathrm{oz}$. She had been fed up to this time on cow's milk, water and sugar 
and the complaint was of continual vomiting and wetting her pillow. She was put on a cow's milk and water feed, thickened with Benger's Food; small, thick, concentrated feeds; $28 \mathrm{oz}$. were gained in 7 days. Diagnosis-Rumination.

\section{Group V. Congenital Hypertrophic Pyloric Stenosis.}

Included in this series were nine cases of the above condition. All were admitted to Hospital for operation. It is most interesting to note that all were males and seven were breast fed. One was having Cow and Gate milk, and the remaining one a cow's milk mixture. Unfortunately in two or three instances the birth weights were not recorded, but in these we have put them at $7 \mathrm{lb}$.

The average age at examination was $6 \cdot 22$ weeks.

The average birth weight was $7 \mathrm{lb} .44 \mathrm{oz}$.

The average weight at examination was $7 \mathrm{lb} .1 \mathrm{oz}$.

The almost negligible gain at the average age of six weeks is perhaps pathognomonic of the condition. The approximate "below level" weight for this class at their average age was $2 \mathrm{lb} .7 \mathrm{oz}$. per infant.

\section{Artificially Fed Group.}

Babies who were entirely artificially fed formed, curiously enough, exactly half of the series of a hundred cases. They presented much the same symptoms and physical signs as the breast-fed cases, but to one of us (A.M.G.), accustomed in South Africa to meet severe diarrhœa in large numbers of artificially-fed infants, the mildness of the diarrhœa or the actual absence of this symptom was striking.

Among the 50 artificially-fed cases there were only two that could be classified as overfed. One was definitely so on cow's milk and sugar, the other was having a full-cream dried milk and was obviously suffering from fat-diarrhœa.

A great similarity will be noticed between the purely breast-fed, the partially breast-fed, and the artificially-fed infants, in that the majority were being underfed either in quantity or quality, and on the increased and balanced diets the weekly weights rose with automatic regularity.

Twenty-seven of the fifty are included in a class (Group VI) as " undercaloried" and these are infants who, at examination, were found to be on a diet deficient in all three elements, carbohydrate, fat and protein.

Sixteen are classified as " under-caloried" generally, but especially in carbohydrate" (Group VII) and four as "underfeeding on carbohydrate only" (Group VIII). Two were overfed (Group X) as mentioned above and one was a well marked case of rickets on an under-caloried diet (Group IX).

In Group VII (the under-caloried generally, but especially in carbohydrate) most of the infants were on dried milks or a cow's milk mixture, with little or no additional sugar.

In the " under-caloried" an increase in the amount of the feed was usually all that was required. The routine in dealing with the artificially underfed was to leave the infant on the feed which it was having, but to increase or alter 
the feed suitably so that its balance was adjusted. The only exception to this was in those cases in which we were dealing with a synthetic dried food.

A number of dried milks are sold to the public with inadequate directions on the tin. Some advocate feeding by age, thus grossly overfeeding the infant born small and weakly, or grossly underfeeding a large and robust infant. The second gross error in these directions is that in the majority the addition of sugar is not mentioned. When it is considered that a heaped teaspoon of the average dried milk added to one ounce of water reconstitutes an ounce of cow's milk, it will be seen that if sugar be not added the infant is being fed on plain cow's milk. The balance of the various elements in cow's milk does not produce an optimum gain in weight, as it is by itself a ketogenic or bilious type of diet. Extra carbohydrate in the form of sugar or starch must be added to metabolise the fat present. Full-cream dried milks should include in their directions the addition of carbohydrate in the form of sugar. We enumerate 20 cases where the chief feature was the badly balanced diet, the deficiency being in carbohydrate.

Group VI. The Under-caloried in carbohydrate, fat and protein.

There were 27 cases of this type, 12 males and 15 females. No difference worthy of record was noticed between the two sexes.

\begin{tabular}{c|c|c|c}
\hline Av. birth wt. & $\begin{array}{c}\text { Av. age at } \\
\text { examination. }\end{array}$ & $\begin{array}{c}\text { Av. wt. at } \\
\text { examination. }\end{array}$ & $\begin{array}{c}\text { Av. gain per week } \\
\text { after correction of diet. }\end{array}$ \\
\hline 7 lb. $8 \mathrm{oz}$. & 10.88 weeks & $8 \mathrm{lb} .14 \mathrm{oz}$. & $11.06 \mathrm{oz}$. \\
\hline
\end{tabular}

The approximate "below level" weight for this class at their average was 2 lb. 14 oz. per infant.

Example.-A female infant, A.B., birth weight $8 \mathrm{lb}$., was seen at the age of 16 weeks weighing $8 \mathrm{lb} . \frac{1}{2} \mathrm{oz}$. Feed up to this time, Almata, 3 teaspoons, water, 6 tablespoons, six feeds, three-hourly. The complaint was of wasting, constipation and vomiting. The child was put on an adequate cow's milk, water and sugar feed with a resulting gain of $19 \frac{1}{2} \mathrm{oz}$., in the first 7 days. Diagnosis-Under-caloried on protein, fat and carbohydrate.

Group VII. The Under-caloried generally but especially in carbohydrate.

Sixteen of these cases presented the following averages :-

\begin{tabular}{c|c|c|c}
\hline Av. birth wt. & $\begin{array}{c}\text { Av. age at } \\
\text { examination. }\end{array}$ & $\begin{array}{c}\text { Av. wt. at } \\
\text { examination. }\end{array}$ & $\begin{array}{c}\text { Av. gain per week } \\
\text { after correction of diet. }\end{array}$ \\
\cline { 1 - 2 } $8.562 \mathrm{lb}$. & 14.25 weeks & $10.75 \mathrm{lb}$. & $10.72 \mathrm{oz.}$ \\
\hline
\end{tabular}

The approximate "below level" weight for this class at their average was 4 lb. 4 oz. per infant. 
Example. A male infant, C.J., birth weight $10 \mathrm{lb}$, was seen at the age of 12 weeks weighing $10 \mathrm{lb} .8 \mathrm{oz}$. The feed up to this time had been cow's milk and water with no sugar. The complaint on coming to Hospital was that the child did not gain. The cow's milk was increased and sugar added; $31 \mathrm{oz}$. were gained in 14 days. Diagnosis-Under-caloried generally, but especially on carbohydrate.

Group VIII. Underfeeding on Carbohydrate only.

All four of these cases were on dried milks, without the addition of sugar.

\begin{tabular}{c|c|c|c}
\hline Av. birth wt. & $\begin{array}{c}\text { Av. age at } \\
\text { examination. }\end{array}$ & $\begin{array}{c}\text { Av. wt. at } \\
\text { examination. }\end{array}$ & $\begin{array}{c}\text { Av. gain per week } \\
\text { after correction of diet. }\end{array}$ \\
\hline $6 \mathrm{lb} . \quad 8.75 \mathrm{oz}$. & 10.28 weeks & $8 \mathrm{lb} .13 .25 \mathrm{oz}$. & $14.56 \mathrm{oz}$. \\
\hline
\end{tabular}

The approximate "below level" weight for this class at their average age was 2 lb. 3 oz. per infant.

Example. A female infant, J.T., birth weight $7 \mathrm{lb} .2$ oz., was seen aged 10 weeks, weighing $9 \mathrm{lb} .5 \mathrm{oz}$. She had been fed up to this time on Cow and Gate milk, with no added sugar. The complaint was of constipation, and occasional vomiting. No change in the feed was made beyond the addition of sugar, with the result that the infant gained $13 \frac{1}{2} \mathrm{oz}$. in 7 days: Diagnosis - Underfeeding on carbohydrate only.

Group IX. Under-caloried, with florid rickets.

The one case of this type was a four months' infants of $12 \mathrm{lb}$. in. weight. It had sweating of the head, was very restless and the mother said it was screaming continually. When examined well-marked cranio-tabes was found. Its feed had been cow's milk and a well known cod-liver-oil-free proprietary preparation reputed to cure rickets.

Group X. Overfeeding (artificially fed).

Only two out of the series could be included in this class.

One was a male infant, birth weight $6 \mathrm{lb} .9 \mathrm{oz}$, , who was seen with diarrhœa and vomiting. At the examination his weight was exactly the same as at birth. He was being fed on a full cream Cow and Gate feed with no sugar added. Put on to half cream Cow and Gate plus sugar with each feed, his diarrhœa and vomiting stopped and he gained $8 \frac{1}{2}$ oz. in 7 days.

The other case of overfeeding is well worth recording, since she was on a feed representing $1 \frac{1}{2}$ pints of cow's milk in 24 hours and having 2 drachms of sugar with each feed-8 feeds in the 24 hours. She was 11 weeks old, weighed $7 \mathrm{lb} .8 \mathrm{oz}$. at birth and was $9 \mathrm{lb} .3 \mathrm{oz}$. at examination. The cow's milk and sugar was reduced and later thickened and she put on $13 \mathrm{oz}$. in 11 days, becoming happier and more comfortable.

Comparisons in "below-level" weight at the time of examination.

The average weights of these infants suffering from underfeeding at the times of examination compared with their birth weights and their respective ages make interesting and instructive reading. 


\begin{tabular}{|c|c|c|c|c|}
\hline \multicolumn{3}{|c|}{ Group. } & No. of cases. & $\begin{array}{l}\text { Average weight } \\
\text { below normal. }\end{array}$ \\
\hline I. & Underfeeding on the breast & . & 28 & 2 lb. $15 \frac{1}{2} \mathrm{oz}$. \\
\hline III. & Underfeeding on the breast, & complementary feeds. & 8 & 2 lb. $10 \mathrm{oz}$ \\
\hline $1 \mathrm{~V}$. & Rumination & . & 4 & (6 lb. $2 \mathrm{oz}$ \\
\hline V. & ('ongenital hypertrophic pyl & stenosis & 9 & $2 \mathrm{lb} . \quad 7 \mathrm{oz}$ \\
\hline VI. & $\begin{array}{c}\text { Artificially fed : Under-calo } \\
\text { and protein .. }\end{array}$ & $\begin{array}{l}\text { in carbohydrate, fat } \\
\ldots \\
. .\end{array}$ & 27 & $2 \mathrm{lb} .14 \mathrm{o \%}$ \\
\hline VII. & Under-caloried generally, bu & ecially in carbohydrate & 16 & $4 \mathrm{lb} . \quad 4 \mathrm{oz}$ \\
\hline VIII. & Underfeeding in carbohydra & nly & 4 & $2 \mathrm{lb} . \quad 3 \mathrm{o} z$ \\
\hline
\end{tabular}

Compared with the average gains per infant per week it is interesting to note that where there was the greatest deficit there was the correspondingly highest gain after treatment. For instance in the rumination cases, the average weight below the normal was $6 \mathrm{lb} .2 \mathrm{oz}$. and after treatment the average gain per week was $15 \cdot 66 \mathrm{oz}$.

It will be clear to anyone reading these notes that certain infants attending the hospital have been excluded. Infants brought up for organic disease, such as congenital heart disease and other malformations, have not been included, nor have those infants with severe digestive upsets who had to be admitted immediately. It is of interest to remark that in the year 1926 and half the year 1927, out of some 4,000 new attendances up to the age of 12 at the clinic of one of us (D.P.), not more than half a dozen cases of severe diarrhœa and vomiting was seen. The infant feeding and nutritional problems, therefore, are entirely different in London from those met with in parts of America and other parts of the world where the climate is warm.

\section{Discession.}

The idea that under-calorie-ing, or starvation, or underfeeding is common in hospital patients is not a new one. Fleming and Hutchison (i) recently showed by careful study of the metabolism of similar cases in Glasgow that the digestion and absorption of the various food elements was perfect, and concluded that the chief error in these wasted infants was in under-calorie-ing, and especially in a deficiency of carbohydrate in the diet. Parsons in his Goulstonian Lectures $\left({ }^{2}\right)$ suggests that in the marasmic infants which he studied carefully, the various food elements were readily absorbed and especially so the fat, although he admits that clinically fat is not well managed in wasted infants. Marriott $\left({ }^{3}\right)$ considers that a very common error in feeding the child who is much under weight is made by under-calorie-ing. Often a very wasted infant requires almost double the caloric requirements of a normal infant. We would suggest that the terms " dyspepsia," " marasmus " and " indigestion" are too readily used; such terms are vague and to us unjustified. 


\section{SUMMary.}

In a series of 100 under-weight infants investigated suffering from gastric symptoms and failure to gain in weight, 50 were wholly or partially breast fed and 50 were artificially fed.

Breast Fed Infants.

1. Twenty-eight cases were definitely underfed on the breast, but when given complementary feeds gained an average $11 \mathrm{oz}$. during the first week.

2. Eight cases were underfed on the breast, but were already having complementary feeds. In these the augmenting of the complementary feeds produced an average gain of $8 \mathrm{oz}$. in the first week.

3. Overfeeding on the breast was observed in one case only in a series of 50 breast fed infants. This bears out the impression that overfeeding on the breast, producing severe disturbance, is a rarity.

4. The most markedly subnormal cases were those of rumination. Dramatic improvement occurred on thickened feeds.

5. Congenital pyloric stenosis was found in 9 of the 50 cases. Artificially Fed Infants.

6. Twenty-seven of these 50 infants were merely under-caloried or starved.

7. There were 16 starved or under-caloried, but especially in carbohydrate.

8. In 4 cases the feed was quite sufficient except in carbohydrate, where there was a gross deficiency.

9. In only one case was there florid rickets. One might have expected a larger number, but the infants, it must be remembered, were very young and were generally underfed.

10. Overfeeding was met with in two cases only, one of which showed fat dyspepsia and the other gross overfeeding with all elements in the diet.

11. Of the 100 cases studied 84 per cent. were under-caloried; 3 per cent. were overfed and 13 per cent. were being starved, the cause being either organic (congenital pyloric stenosis) or functional (ruminations).

\section{Conclusion.}

From the above examination of this series of 100 cases, and from the figures arrived at, we feel justified in concluding that the chief cause of gastric symptoms and failure to gain in weight in hospital out-patient infants under six months is starvation.

\section{REFERENC'ES.}

1. Fleming, G. B., and Hutchison, H. S., Quart. J. Med., Oxf., 1924, XVII, 339.

2. Parsons, L. G., Lancet, Lond., 1924, i, 687.

3. Marriott, W. McK., Am. J. Dis. Child., Chic., 1920, XX . 